\title{
Association between Anxiety Disorders and Socio-Demographic Characteristics among School Going Children in Nairobi, Kenya
}

\author{
Mathenge Justus*, Ayuya Caroline, Ongaro Kennedy, Khasakhala Lincolin \\ Daystar University, Kenya
}

*Corresponding Author: Mathenge Justus, Daystar University, Kenya

\begin{abstract}
The purpose of this study was determine association between Anxiety Disorder and Sociodemographic characteristics among School going children in Nairobi, Kenya. The study employed a descriptive study design utilizing purposeful sampling frame.The sample size of 92 was drawn from classes 3 to 7 at Our Lady Queen of Peace and Amani primary schools. Data was collected using a self-administered Socio-demographic and the Screen for Child Anxiety Related Disorders (SCARED) - Child Version. Findings indicated that the socio-demographic characteristics; $50 \%$ of the respondents' parents were not living together with a significant number of the pupils living with their single mother compared to single fathers. Half of the respondents were from very poor socio-economic background as depicted by materials used in constructing houses their family lived-in (mud 2.7\%, $8.0 \%$ wooden materials and $37.1 \%$ iron sheets) and source of water for domestic use, where $31.7 \%$ drew water from a common tab outside their houses.
\end{abstract}

Keywords: Anxiety diorders, children, Association, Socio demographic, Kenya

\section{INTRODUCTION}

Anxiety disorders in children in a school setting are characterized by excessive worry concerning the quality of their work, performance in examinations and how their future will be like (McLoone, Hudson, \&Rapee 2006). Children worry that they are not performing as well as they should and often seek reassurance from their teachers, parents and peers (Masi, Mucci, Favilla, Romano, \&Poli, 1999). According to the American Psychiatric Association (APA, 2013) anxiety disorders are characterized by excessive fear, anxiety and related behavioral disturbances.

Eric Erikson's psychosocial development theory postulates that children between 6 years and puberty are at a stage where they learn their culture successfully or face feelings of inferiority (Papalia, Olds, \& Feldman, 2004). Children start becoming self-conscious and this situation makes them to either gain self-confidence or develop low self-esteem depending on the environment in which they are growing. Children start to think logically and are well equipped to appreciate formal schooling. It is at this stage of development that children should be taught skills to enable them identify anxiety feelings, to regulate them and to learn how to cope with them. Children are helped to be competent to handle problems that confront them on a regular basis.

The causes of anxiety in children are many. Rural/urban migration of parents looking for greener pastures results in many problems: socio-economic hardships of finding employment and adequate housing, negative influence on adherence to learned cultural practices and norms (The World Bank, 2008). Children between 8 and 13 years are in a stage in their development when they are supposed to be learning and internalizing the culture of the society (Papalia et al., 2004). Children in this study were exposed to this kind of environment where they continue to experience hard socioeconomic realities at their homes. This kind of situation and environment predisposes them to anxiety.

Another very important consideration that could be cited for the development of anxiety in children is lack of what Ainsworth (1973) and Bowlby (1969) referred to as a deep and enduring emotional bond between children and their caregivers. This bond is said to be present across time and space and when that desire for regular contact is denied, distress can be caused. Indeed, one of the main causes of anxiety among children is separation from significant others.

Several studies have linked a number of several socio demographic charecteristics and anxiety disorder. Papalia asserted that there is a linkage between poverty, family stress and children's social 
and emotional problems. Children from a poor background are more likely to experience emotional and behavioral problems than children from well-to-do families. Negative emotional states and parenting practices of poor parents affect the health and cognitive performance of their children.

In a review of depressed mood and anxiety by socio-economic status in Iranian children aged 10-15 years Lemstra, Neudorf, Kunst, Warren, \&Bennett (2008) concluded that prevalence of anxiety disorders was as high as $20 \%$ and that lower socioeconomic status is associated with higher rate of anxiety disorder in children. In a report dated July 2009 on mental health, poverty and development in Brazil, World Health Organization (WHO) reported that children living in poverty were more than five times likely to develop mental disorders than middle class children.

Vine et al. (2012) asserted in an article on better understanding of family and neighborhood level of socioeconomic characteristics in the development of anxiety disorders in children that anxiety symptoms emerge in childhood. They further argued that these disorders may persist into adulthood and cause severe emotional and health consequences. They recommended that knowledge of the risk factors and early diagnosis would be useful for provision of intervention efforts. In another study investigating the relationship between socioeconomic status and mental disorders in children, Miech et al. (1999) found that mental disorders and in particular anxiety disorders were more likely to be found in children whose families are categorized as of low socioeconomic status than in children in well to do families. In general, internalizing disorders like anxiety disorder were more prevalent in children in families with low incomes than in middle and higher income brackets. Herzer, Godiwala, Hommel, Driscoll, Mitchell, Crosby, Piazza-Waggoner, Zeller, \& Modi, (2010) argued that low socioeconomic status results in negative family functioning while high socio-economic status result in positive family functioning (Woodson, Thakkar, Burbage, Kichler, \& Nabors, 2015).

In a study of the relationship between quality of life and anxiety symptoms and the found that age, gender, residential background, and parental education levels had moderating effects moderating effects of socio-demographic characteristics in Taiwanese children, Yen et al. (2011). They defined quality of life as individuals' perception of their own position in life in the context of the culture and value systems in which they live, and in relation to their goals, expectations, standards, and concerns" (Yen et al., 2011). They recommended that when developing strategies for the improvement of quality of life for children, interventions for anxiety symptoms should be included. Richter et al. (2012) in a study to explain socio-economic differences in adolescent self-rated health in relation to contribution of material, psychosocial and behavioral factors, argued that material factors exerted directly and indirectly greater influence on health but through psychosocial and behavioral factors. According to UNICEF (2013), one cause of mental distress often cited by children and observers is the stigma that comes with being seen as a child of the underprivileged.

Jenkins et al. (2012) in their study of prevalence of common mental disorders in a rural district in Kenya argued thatthere wasan association between mental disorders and socio-demographic and socio-economic characteristics. They found a mental disorder prevalence rate of $10.8 \%$ in a population of 50,000 people. This compares well with a prevalence rate of $14.3 \%$ among children in the sub-Saharan Africa (Cortina et al. 2012).

This study determined the association of anxiety disorders among school going children in Nairobi, Kenya.

\section{Materials And Methods}

The employed a descriptive research design. The target population in this study comprised all students in classes 3 to 7 at Our Lady of Peace and Amani Primary schools in Nairobi County. These students were approximately 198 in number and they ranged from class 3 to 7.Both schools are day schools for boys and girls.

The calculation of the sample size of 92 respondents was based on anxiety disorders prevalence rate given by Ndetei et al. (2011) who asserted that a large number of the Kenyan population has anxiety disorders and that anxiety disorders prevalence rate among children was at $12.9 \%$. The size of the sample was calculated using the method adopted from Chow, Shao \& Wang (2003).

\section{INCLUSION AN EXCLUSION CRITERIA}

All the children in the schools selected were those between 8 and 13 years of age. Children outside this age bracket were be allowed to participate. Also, children who presented with psychosocial 
Association between Anxiety Disorders and Socio-Demographic Characteristics among School Going Children in Nairobi, Kenya

disabilities challenged were not included in this study. Children who did not assent to be included in the study or whose parents who did not consent to have them participate in the study were also excluded.

\subsection{Data Collection Instruments}

The following data collection instruments were found appropriate for the target population: the SocioDemographic Questionnaire. This questionnaire was developed and administered by the researcher. The purpose of this questionnaire was to collect details regarding the participants' age, gender, class, ethnicity, residence and type of accommodation, religious affiliation, parent(s) marital status, parent(s) employment and income and number of siblings. It also obtained data regarding any mediating and/or confounding variables that would have to be controlled for. For example family functioning, domestic violence, illness in the family and refusal to go to school were considered. The questionnaire was completed at the beginning of the intervention. The Screen for Child Anxiety Related Disorders (SCARED) - Child Version developed in 1995 by Birmaher was also used. It is rated on a Likert Scale from 0 to 2. Zero (0) indicates a not true or hardly ever true response. 1 indicates "somewhat true" or "sometimes true" response. 2 indicates "very true" or "often true" response.

\section{Results}

Table 1 to 7 present association between specific anxiety disorders and social demographic data. There was no significant difference between cumulative score of anxiety on the SCARED total score at cut off point of 25 and socio-demographic characteristics as shown in table 1.

Table1: Association Anxiety Disorder and Socio-demographic Characteristics

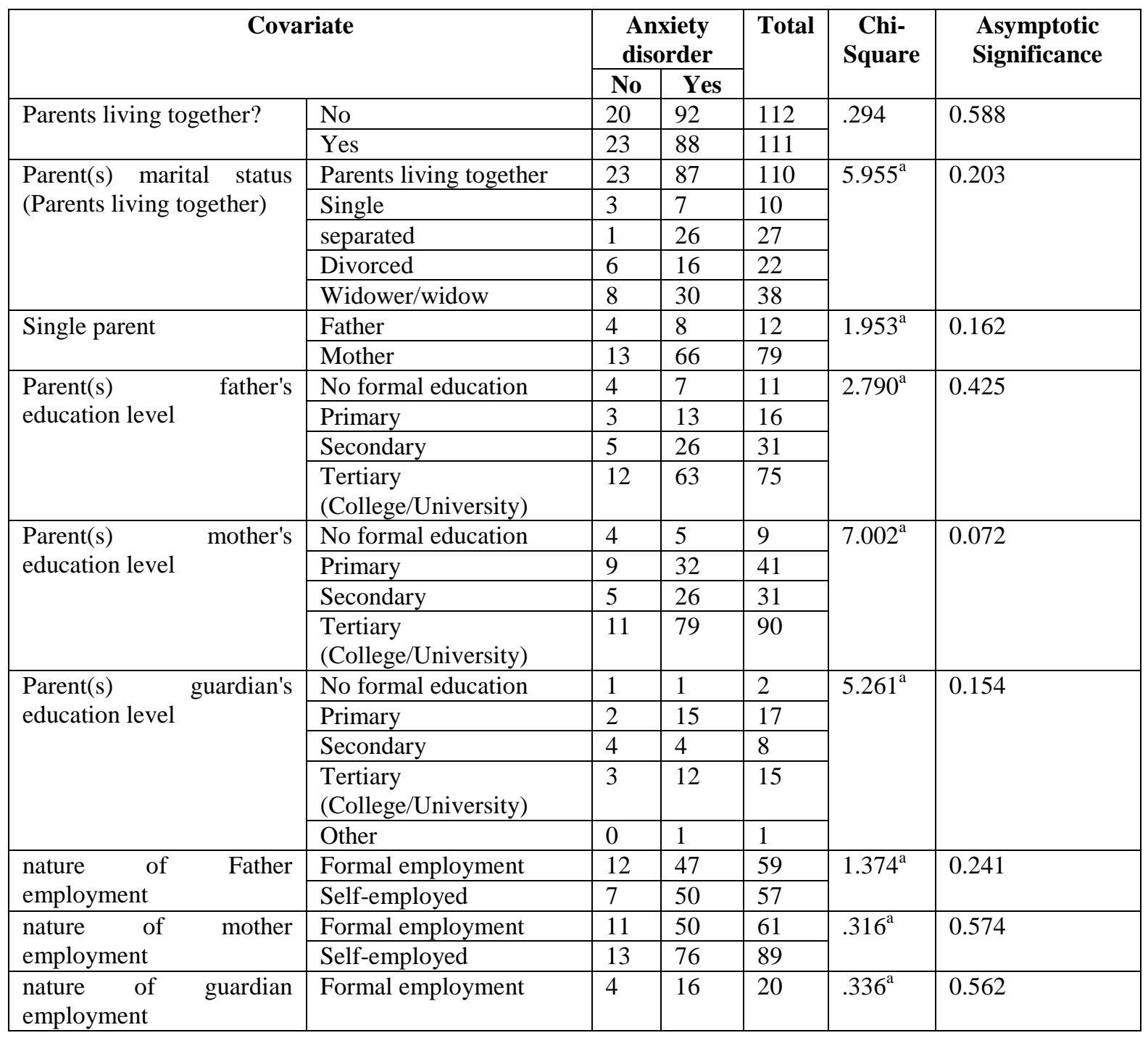


Association between Anxiety Disorders and Socio-Demographic Characteristics among School Going Children in Nairobi, Kenya

Table 2 presents association between panic disorder and socio-demographic characteristics. There is only a significant association of panic disorder and single parents where the proportion of children living with mothers (53) with panic disorder was higher than proportion of children with panic living with single fathers (4). This indicates that children living with a single mother panicked more compared to those who lived with a single father.

Table3: Association between Panic Disorder and Socio-demographic Characteristics

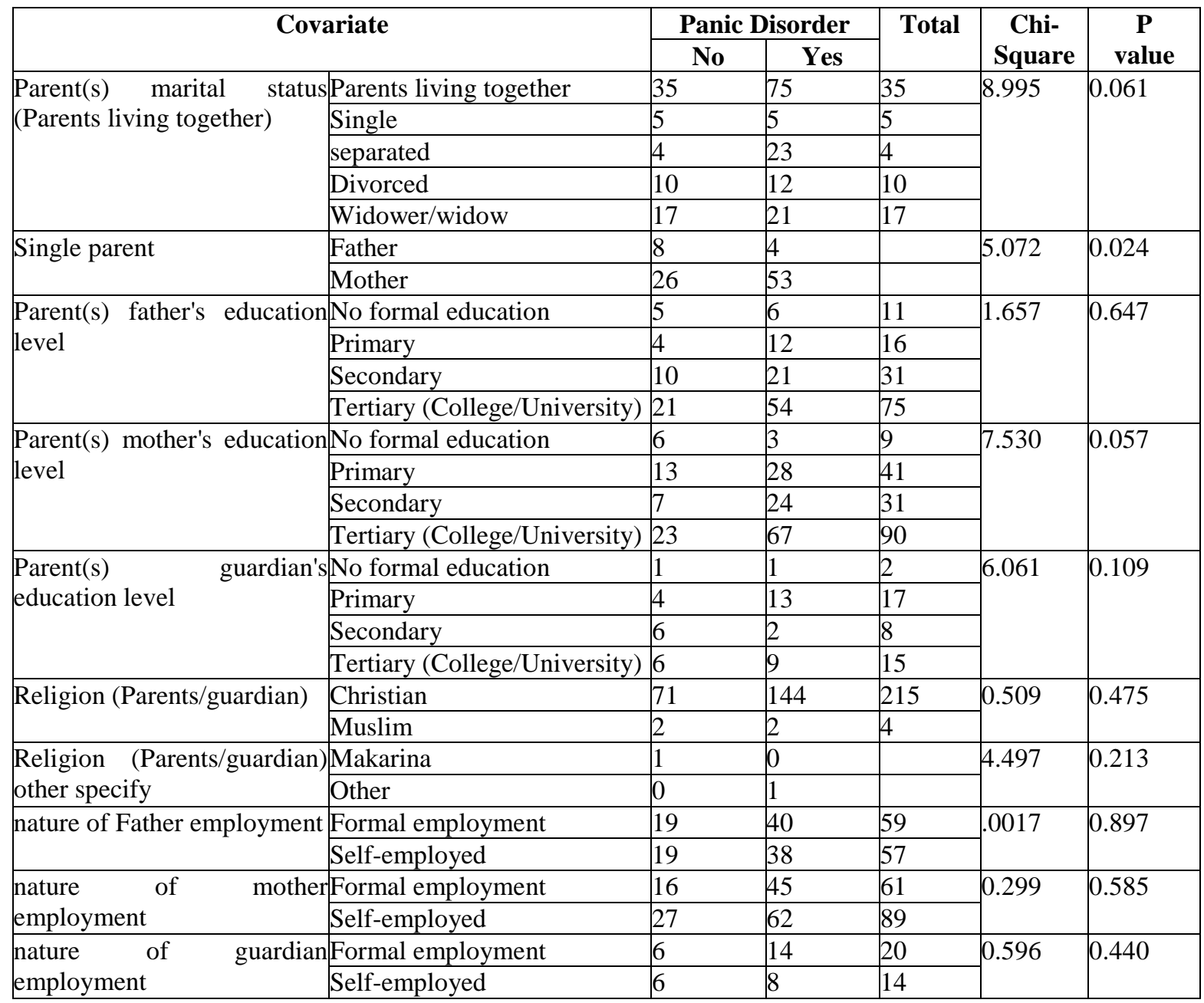

"Significant at $\mathrm{p}<0.05$ bolded

Table 4 presents association between generalized anxiety disorder and socio-demographic characteristics. There was no significant difference between generalized anxiety disorder and sociodemographic characteristics.

Table4: Association between Generalized Anxiety Disorder and socio-demographic Characteristics

\begin{tabular}{|c|c|c|c|c|c|c|}
\hline \multirow{2}{*}{\multicolumn{2}{|c|}{ Covariate }} & \multicolumn{2}{|c|}{$\begin{array}{c}\text { Generalized } \\
\text { anxiety disorder }\end{array}$} & \multirow[t]{2}{*}{ Total } & \multirow[t]{2}{*}{$\begin{array}{l}\text { Chi- } \\
\text { Square }\end{array}$} & \multirow[t]{2}{*}{$\begin{array}{c}\mathbf{p} \\
\text { value }\end{array}$} \\
\hline & & No & Yes & & & \\
\hline \multirow{5}{*}{$\begin{array}{l}\text { Parent(s) marital status } \\
\text { (Parents living together) }\end{array}$} & Parents living together & 70 & 40 & 110 & \multirow[t]{5}{*}{8.943} & \multirow[t]{5}{*}{0.063} \\
\hline & Single & 7 & 3 & 10 & & \\
\hline & separated & 9 & 18 & 27 & & \\
\hline & Divorced & 12 & 10 & 22 & & \\
\hline & Widower/widow & 21 & 17 & 38 & & \\
\hline \multirow[t]{2}{*}{ Single parent } & Father & 7 & 5 & 12 & \multirow[t]{2}{*}{0.436} & \multirow[t]{2}{*}{0.509} \\
\hline & Mother & 38 & 41 & 79 & & \\
\hline \multirow{4}{*}{$\begin{array}{l}\text { Parent(s) father's education } \\
\text { level }\end{array}$} & No formal education & 8 & 3 & 11 & \multirow[t]{4}{*}{6.63} & \multirow[t]{4}{*}{0.085} \\
\hline & Primary & 7 & 9 & 16 & & \\
\hline & Secondary & 13 & 18 & 31 & & \\
\hline & $\begin{array}{l}\text { Tertiary } \\
\text { (College/University) }\end{array}$ & 48 & 27 & 75 & & \\
\hline
\end{tabular}


Association between Anxiety Disorders and Socio-Demographic Characteristics among School Going Children in Nairobi, Kenya

\begin{tabular}{|c|c|c|c|c|c|c|}
\hline \multirow{4}{*}{$\begin{array}{l}\text { Parent(s) mother's education } \\
\text { level }\end{array}$} & No formal education & 6 & 3 & 9 & \multirow[t]{4}{*}{1.021} & \multirow[t]{4}{*}{0.796} \\
\hline & Primary & 22 & 19 & 41 & & \\
\hline & Secondary & 16 & 15 & 31 & & \\
\hline & $\begin{array}{l}\text { Tertiary } \\
\text { (College/University) }\end{array}$ & 53 & 37 & 90 & & \\
\hline \multirow{4}{*}{$\begin{array}{l}\text { Parent(s) guardian's education } \\
\text { level }\end{array}$} & No formal education & 2 & 0 & 2 & \multirow[t]{4}{*}{3.008} & \multirow[t]{4}{*}{0.390} \\
\hline & Primary & 7 & 10 & 17 & & \\
\hline & Secondary & 3 & 5 & 8 & & \\
\hline & $\begin{array}{l}\text { Tertiary } \\
\text { (College/University) }\end{array}$ & 8 & 7 & 15 & & \\
\hline \multirow[t]{2}{*}{ Religion (Parents/guardian) } & Christian & 122 & 93 & 215 & \multirow[t]{2}{*}{0.073} & \multirow[t]{2}{*}{0.787} \\
\hline & Muslim & 2 & 2 & 4 & & \\
\hline \multirow{2}{*}{$\begin{array}{l}\text { Religion (Parents/guardian) } \\
\text { other specify }\end{array}$} & Makarina & 1 & 0 & 1 & \multirow[t]{2}{*}{2.84} & \multirow[t]{2}{*}{0.416} \\
\hline & Other & 0 & 1 & 1 & & \\
\hline \multirow[t]{2}{*}{ nature of Father employment } & Formal employment & 40 & 19 & 59 & \multirow[t]{2}{*}{2.196} & \multirow[t]{2}{*}{0.138} \\
\hline & Self-employed & 31 & 26 & 57 & & \\
\hline \multirow[t]{2}{*}{ nature of mother employment } & Formal employment & 34 & 27 & 610 & \multirow[t]{2}{*}{0.003} & \multirow[t]{2}{*}{0.957} \\
\hline & Self-employed & 50 & 39 & 89 & & \\
\hline \multirow[t]{2}{*}{ nature of guardian employment } & Formal employment & 8 & 12 & 20 & \multirow[t]{2}{*}{0.334} & \multirow[t]{2}{*}{0.563} \\
\hline & Self-employed & 7 & 7 & 14 & & \\
\hline
\end{tabular}

Table 5 presents association between separation anxiety disorder and socio-demographic characteristics. There is only a significant association of separation anxiety disorder and single parents where the proportion of children living with single parents and had separation anxiety disorder was higher than proportion of children with separation anxiety disorder living with both parents. This indicates that children living with a single parent were more likely to develop separation anxiety disorder compared to those who lived with both parents.

Table5: Association between Separation Anxiety disorder and Socio-demographic Characteristics

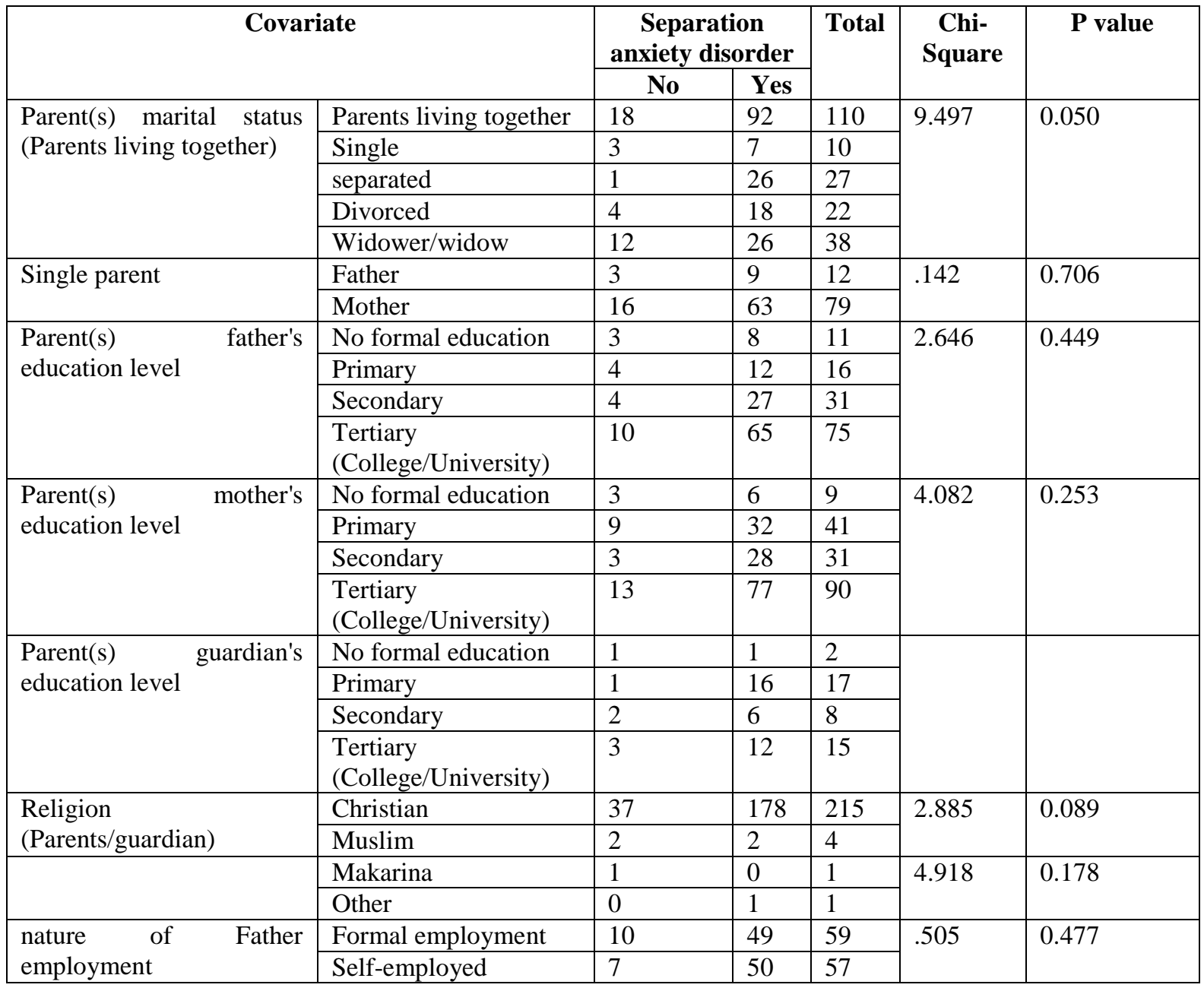


Association between Anxiety Disorders and Socio-Demographic Characteristics among School Going Children in Nairobi, Kenya

\begin{tabular}{|c|c|c|c|c|c|c|c|}
\hline \multirow{2}{*}{$\begin{array}{l}\text { nature of } \\
\text { employment }\end{array}$} & \multirow{2}{*}{ mother } & Formal employment & 13 & 48 & 61 & \multirow[t]{2}{*}{1.597} & \multirow[t]{2}{*}{0.206} \\
\hline & & Self-employed & 12 & 77 & 89 & & \\
\hline \multirow{2}{*}{$\begin{array}{l}\text { nature of } \\
\text { employment }\end{array}$} & guardian & Formal employment & 3 & 17 & 20 & \multirow[t]{2}{*}{.003} & \multirow[t]{2}{*}{0.95} \\
\hline & & Self-employed & 2 & 12 & 14 & & \\
\hline
\end{tabular}

*Significant at $\mathrm{p}<0.05$ bolded

Table 6 presents association between social anxiety disorder and socio-demographic characteristics. There is only a significant association of social anxiety disorder and single parents where the proportion of children living with single parents and had social anxiety disorder was higher than proportion of children with social anxiety disorder living with both parents. This indicates that children living with a single parent were more likely to have social anxiety disorder compared to those who lived with both parents.

Table6: Association between Social Anxiety Disorder and Socio-demographic Characteristics

\begin{tabular}{|c|c|c|c|c|c|c|}
\hline \multirow{2}{*}{\multicolumn{2}{|c|}{ Covariate }} & \multicolumn{2}{|c|}{$\begin{array}{l}\text { Social anxiety } \\
\text { disorder }\end{array}$} & \multirow[t]{2}{*}{ Total } & \multirow[t]{2}{*}{$\begin{array}{l}\text { Chi- } \\
\text { Square }\end{array}$} & \multirow[t]{2}{*}{$\begin{array}{c}\mathbf{p} \\
\text { value }\end{array}$} \\
\hline & & No & Yes & & & \\
\hline \multirow{5}{*}{$\begin{array}{l}\text { Parent(s) marital status } \\
\text { (Parents living together) }\end{array}$} & Parents living together & 52 & 58 & 110 & \multirow[t]{5}{*}{13.305} & \multirow[t]{5}{*}{0.010} \\
\hline & Single & 4 & 6 & 10 & & \\
\hline & separated & 3 & 24 & 27 & & \\
\hline & Divorced & 6 & 16 & 22 & & \\
\hline & Widower/widow & 15 & 23 & 38 & & \\
\hline \multirow[t]{2}{*}{ Single parent } & Father & 6 & 6 & 12 & \multirow[t]{2}{*}{2.400} & \multirow[t]{2}{*}{0.121} \\
\hline & Mother & 22 & 57 & 79 & & \\
\hline \multirow{4}{*}{$\begin{array}{l}\text { Parent(s) father's education } \\
\text { level }\end{array}$} & No formal education & 6 & 5 & 11 & \multirow[t]{4}{*}{1.978} & \multirow[t]{4}{*}{0.577} \\
\hline & Primary & 6 & 10 & 16 & & \\
\hline & Secondary & 10 & 21 & 31 & & \\
\hline & $\begin{array}{l}\text { Tertiary } \\
\text { (College/University) }\end{array}$ & 32 & 43 & 75 & & \\
\hline \multirow{4}{*}{$\begin{array}{ll}\text { Parent(s) mother's } \\
\text { education level }\end{array}$} & No formal education & 4 & 5 & 9 & \multirow[t]{4}{*}{.875} & \multirow[t]{4}{*}{0.832} \\
\hline & Primary & 13 & 28 & 41 & & \\
\hline & Secondary & 11 & 20 & 31 & & \\
\hline & $\begin{array}{l}\text { Tertiary } \\
\text { (College/University) }\end{array}$ & 35 & 55 & 90 & & \\
\hline \multirow{4}{*}{$\begin{array}{ll}\text { Parent(s) } & \text { guardian's } \\
\text { education level } & \end{array}$} & No formal education & 1 & 1 & 2 & \multirow[t]{4}{*}{4.634} & \multirow[t]{4}{*}{0.201} \\
\hline & Primary & 3 & 14 & 17 & & \\
\hline & Secondary & 3 & 5 & 8 & & \\
\hline & $\begin{array}{l}\text { Tertiary } \\
\text { (College/University) }\end{array}$ & 8 & 7 & 15 & & \\
\hline \multirow[t]{2}{*}{ Religion (Parents/guardian) } & Christian & 83 & 132 & 215 & \multirow[t]{2}{*}{.215} & \multirow[t]{2}{*}{0.643} \\
\hline & Muslim & 2 & 2 & 4 & & \\
\hline \multirow{2}{*}{$\begin{array}{l}\text { Religion (Parents/guardian) } \\
\text { other specify }\end{array}$} & Makarina & 1 & 0 & & \multirow[t]{2}{*}{3.798} & \multirow[t]{2}{*}{0.284} \\
\hline & Other & 0 & 1 & & & \\
\hline \multirow{2}{*}{$\begin{array}{l}\text { nature of } \\
\text { employment }\end{array}$} & Formal employment & 23 & 36 & 59 & \multirow[t]{2}{*}{.522} & \multirow[t]{2}{*}{0.470} \\
\hline & Self-employed & 26 & 31 & 57 & & \\
\hline \multirow{2}{*}{$\begin{array}{l}\text { nature of mother } \\
\text { employment }\end{array}$} & Formal employment & 25 & 36 & 61 & 1.811 & 0.178 \\
\hline & Self-employed & 27 & 62 & 89 & & \\
\hline nature of guardian & Formal employment & 8 & 12 & 20 & .028 & 0.868 \\
\hline employment & Self-employed & 6 & 8 & 14 & & \\
\hline
\end{tabular}

*Significant at $\mathrm{p}<0.05$ bolded

Table 9 presents association between significant school refusal and socio-demographic characteristics. There was no significant difference between significant school refusal and socio-demographic characteristics.

Table7: Association between Significant School Avoidance and Socio-demographic Characteristics

\begin{tabular}{|lc|l|c|c|c|c|c|}
\hline \multicolumn{3}{|c|}{ Covariate } & \multicolumn{2}{c|}{$\begin{array}{c}\text { Significant } \\
\text { school avoidance }\end{array}$} & Total & \multirow{2}{*}{$\begin{array}{c}\text { Chi- } \\
\text { Square }\end{array}$} & $\begin{array}{c}\text { p } \\
\text { value }\end{array}$ \\
\cline { 4 - 7 } & No & Yes & & & \\
\hline Parent(s) & marital status & Parents living together & 70 & 39 & 109 & 6.267 & 0.180 \\
\hline
\end{tabular}


Association between Anxiety Disorders and Socio-Demographic Characteristics among School Going Children in Nairobi, Kenya

\begin{tabular}{|c|c|c|c|c|c|c|}
\hline \multirow[t]{4}{*}{ (Parents living together) } & Single & 7 & 3 & 10 & & \\
\hline & separated & 22 & 5 & 27 & & \\
\hline & Divorced & 19 & 3 & 22 & & \\
\hline & Widower/widow & 26 & 12 & 38 & & \\
\hline \multirow[t]{2}{*}{ Single parent } & Father & 9 & 3 & 12 & \multirow[t]{2}{*}{.005} & \multirow[t]{2}{*}{0.943} \\
\hline & Mother & 60 & 19 & 79 & & \\
\hline \multirow{4}{*}{$\begin{array}{l}\text { Parent(s) father's education } \\
\text { level }\end{array}$} & No formal education & 9 & 2 & 11 & \multirow[t]{4}{*}{2.232} & \multirow[t]{4}{*}{0.526} \\
\hline & Primary & 9 & 7 & 16 & & \\
\hline & Secondary & 21 & 10 & 31 & & \\
\hline & $\begin{array}{l}\text { Tertiary } \\
\text { (College/University) }\end{array}$ & 46 & 28 & 74 & & \\
\hline \multirow{4}{*}{$\begin{array}{l}\text { Parent(s) mother's education } \\
\text { level }\end{array}$} & No formal education & 6 & 3 & 9 & \multirow[t]{4}{*}{3.018} & \multirow[t]{4}{*}{0.389} \\
\hline & Primary & 28 & 13 & 41 & & \\
\hline & Secondary & 24 & 7 & 31 & & \\
\hline & $\begin{array}{l}\text { Tertiary } \\
\text { (College/University) }\end{array}$ & 54 & 35 & 89 & & \\
\hline \multirow{4}{*}{$\begin{array}{ll}\text { Parent(s) } & \text { guardian's } \\
\text { education level } & \end{array}$} & No formal education & 2 & 0 & 2 & \multirow[t]{4}{*}{2.195} & \multirow[t]{4}{*}{0.533} \\
\hline & Primary & 12 & 5 & 17 & & \\
\hline & Secondary & 7 & 1 & 8 & & \\
\hline & $\begin{array}{l}\text { Tertiary } \\
\text { (College/University) }\end{array}$ & 13 & 2 & 15 & & \\
\hline \multirow[t]{2}{*}{ Religion (Parents/guardian) } & Christian & 149 & 65 & 214 & \multirow[t]{2}{*}{0.710} & \multirow[t]{2}{*}{0.399} \\
\hline & Muslim & 2 & 2 & 4 & & \\
\hline \multirow{2}{*}{$\begin{array}{l}\text { Religion (Parents/guardian) } \\
\text { other specify }\end{array}$} & Makarina & 1 & 0 & 1 & \multirow[t]{2}{*}{1.334} & \multirow[t]{2}{*}{0.721} \\
\hline & Other & 1 & 0 & 1 & & \\
\hline \multirow{2}{*}{$\begin{array}{l}\text { nature of } \\
\text { employment }\end{array}$} & Formal employment & 36 & 22 & 58 & \multirow[t]{2}{*}{0.015} & \multirow[t]{2}{*}{0.904} \\
\hline & Self-employed & 36 & 21 & 57 & & \\
\hline \multirow{2}{*}{$\begin{array}{l}\text { nature of mother } \\
\text { employment }\end{array}$} & Formal employment & 41 & 20 & 61 & \multirow[t]{2}{*}{0.000} & \multirow[t]{2}{*}{0.983} \\
\hline & Self-employed & 59 & 29 & 88 & & \\
\hline \multirow{2}{*}{$\begin{array}{l}\text { nature of guardian } \\
\text { employment }\end{array}$} & Formal employment & 12 & 8 & 20 & \multirow[t]{2}{*}{2.623} & \multirow[t]{2}{*}{0.105} \\
\hline & Self-employed & 12 & 2 & 14 & & \\
\hline
\end{tabular}

\section{DISCUSSION}

The study sought to establish whether social demographic factors were a significant correlate of anxiety disorders. In this study, children in the control and experimental groups condition did not differ significantly on demographic variables or level of anxiety. Most social demographic factors were not found to be statistically significant influence on anxiety disorders. The findings in Table 6 indicated that there was only a significant association of separation anxiety disorder and single parents where the proportion of children living with single parents and had separation anxiety disorder was higher than proportion of children with separation anxiety disorder living with both parents. This indicates that children living with a single parent were more likely to develop separation anxiety disorder compared to those who lived with both parents. This could be attributed to lack of attachment figure as reported in study of 188 children in an anxiety disorders clinic determined that there was an equal gender distribution and an earlier age of onset (mean of 7.5 years) of separation anxiety than in other anxiety disorders, and that these children were more likely to come from low socioeconomic status and single-parent homes (Ongudele, 2018).

These findings are supported by various studies. In a study of the relationship between quality of life and anxiety symptoms and the moderating effects of socio-demographic characteristics in Taiwanese children Yen et al. (2011) found that age, gender, residential background, and parental education levels were not significant however moderating effects had however children who lived with single parents were found to have separation anxiety.

Richter et al. (2012) in a study to explain socio-economic differences in children self-rated health in relation to contribution of material, psychosocial and behavioral factors argue that material factors exert directly and indirectly greater influence on health but through psychosocial and behavioral factors. To reduce anxiety disorders among school going children. 


\section{CONCLUSION}

Many school going children live with anxiety disorders that have not been treatment. These anxiety disorders are closely associated with various socio demographic characteristics. These results highlight the need for better organization planning of services taking into account that the majority of children with anxiety disorders will not visit a mental health professional either due to stigmatization or lack of funds to take care of the costs. Half of the respondents from the study, come from low socio economic status which is risk factor for anxiety disorder. disorders. It is therefore necessary for all Kenyan schools to consider mental health programs in school settings that are geared towards addressing and treating anxiety disorders.

\section{REFERENCES}

[1] American Psychiatric Association (2013). The Diagnostic and Statistical Manual of Mental Disorders fifth Edition. Washington, DC, American Psychiatric Association

[2] Bowlby, J. (1969). Attachment and loss, Vol.1, New York, Basic Books.Cortina, M.A., Sodha, A., Fazel, M., \&Ramchandani, P.G. (2012). Prevalence of child mental

[3] Jenkins, R., Njenga, F., Okonji, M., Kigamwa, P., Baraza, M., Ayuyo, J., Singleton, N., McMannus, S., \& Kiima, D. (2012). Prevalence of common mental disorders in a rural district of Kenya and sociodemographic risk factors. International journal of environmental research and public health 2012, 9, 1810 1819.

[4] Masi, G., Mucci, M., Favilla, L., Romano, R., \&Poli, P. (1999). Symptomatology and Comorbidity of generalized anxiety disorder in children. Comprehensive Psychiatry, 40, 210-215

[5] McLoone J., Hudson J.L., \&Rapee R.M. (2006). Treating anxiety disorders in a school setting. Education and treatment of children Vol.29, 2, 219-242. West Virginia University Press, NSW 2109 Australia.

[6] Ndetei, D.M., Khasakhala, L., Nyambola, L., Ongecha-Owuor, F., Seedat, S., Mutiso, V., Kokonya, D., \&Odhiambo, G. (2008). The prevalence of anxiety and depression symptoms and syndromes in Kenyan children. Journal of child and adolescent health,Vol. 20, 1, 33-51, Nairobi, Kenya.

[7] Ndetei, D.M., Khasakhala, L.I., Mbwayo, A.W., Mutiso, V., (2011). Epidemiological patterns of anxiety disorders in Kenya, Africa medical health foundation (AMHF) Kenya. www.intechopen.com Retrieved on 8.7.2016

[8] Papalia, D. E., Olds, S. W., \& Feldman, R. D. (2004). Human development, ninth edition, New Delhi, Tata McGraw-Hill

[9] Papalia, D. E., Olds, S. W., \& Feldman, R. D. (2004). Human development, ninth edition, New Delhi, Tata McGraw-Hill

[10] Richter, M., Moor, I., van Lenthe, F.J. (2012) Explaining socioeconomic differences in Adolescent selfrated health: the contribution of material, psychosocial and behavioral factors. Journal of Epidemiology and community health, Vol. 66, No. 8, 691-697. JSTOR

[11] UNICEF (2013). Children in the urban World. The state of the World's children (2012): New York

[12] Vine, M., Stoep, A.V., Bell, J., Rhew, I.C., Gudmundsen, G., \& McCauley, E. (2012). Associations between household and neighborhood income and anxiety symptoms in young children. Depression and Anxiety 29:824-832. Wiley Periodicals, Inc

Citation: Mathenge Justus, et.al. "Association between Anxiety Disorders and Socio-Demographic Characteristics among School Going Children in Nairobi, Kenya". International Journal of Humanities Social Sciences and Education (IJHSSE), vol. 6, no.12, 2019, pp. 139-146. doi: http://dx.doi.org/10.20431/23490381.0612012.

Copyright: (1) 2019 Authors. This is an open-access article distributed under the terms of the Creative Commons Attribution License, which permits unrestricted use, distribution, and reproduction in any medium, provided the original author and source are credited. 